\title{
Exploring the relationship between ecosystems and human well-being by understanding the preferences for natural capital-based and produced capital-based ecosystem services
}

\author{
Keiko Hori ${ }^{1} \cdot$ Chiho Kamiyama $^{1} \cdot$ Osamu Saito ${ }^{1}[$
}

Received: 3 July 2018 / Accepted: 17 September 2018

(c) Springer Japan KK, part of Springer Nature 2018

\begin{abstract}
Scenario analysis is recognized as a useful tool for exploring future changes in the relationships between ecosystem services (ES) and human well-being. This analysis should be carried out not only by experts but also by relevant stakeholders such as the public. In this study, we investigated the preference of Japanese people toward natural and produced capital-based ES by distributing questionnaires to the public for exploring the direction of ES utilization in the future. Respondents with diverse backgrounds living in Tokyo and Nanao city in Ishikawa prefecture answered a series of questions about the extent to which they preferred natural or produced capital-based ES. As the general tendency of the results, the preferences for ES from the natural capitals were stronger than ES from produced capital. The trends varied, depending on the attributes of the respondents. The stronger preference for natural capital-based ES was possibly a positive indication that utilizing ES from the natural capitals was significantly beneficial for human well-being. The results were informative to understand public perception on key aspects of ES utilization scenarios, including their preferences for specific types of ES.
\end{abstract}

Keywords Ecosystem services $\cdot$ Natural capital $\cdot$ Produced capital $\cdot$ Preference

\section{Introduction}

The Millennium Ecosystem Assessment conferred the term "ecosystem services" (ES) for the benefits that humans obtain from the ecosystem and stated that ES have strong associations with human well-being (MA 2005). ES are categorized into supporting services (such as nutrient cycling), provisioning services (such as food or water supply), regulating services (such as climate regulation), and cultural

Handled by Shunsuke Managi, Kyushu University, Japan.

Electronic supplementary material The online version of this article (https://doi.org/10.1007/s11625-018-0632-8) contains supplementary material, which is available to authorized users.

Osamu Saito

saito@unu.edu

1 United Nations University Institute for the Advanced Study of Sustainability, 5-53-70 Jingumae, Shibuya, Tokyo 150-8925, Japan services (such as spiritual effects). Such ecosystem services are integral to human well-being in various aspects.

Scenario analysis has been recognized as a useful tool for exploring plausible future changes in the relationships between ES and humans to consider alternative paths to meet uncertain social and environmental changes (van Vuuren 2012; IPBES 2016). The Intergovernmental Platform on Biodiversity and Ecosystem Services (IPBES) stated that scenarios and models could provide an effective means of addressing the relationships between nature, nature's benefits to people, and a good quality of life, and could thereby add considerable value to using the best available scientific, indigenous, and local knowledge in assessments and decision support (IPBES 2016). Scenario development and analysis have been carried out widely for agenda setting, policy design, and implementation of ES on global, national, and regional scales such as Millennium Ecosystem Assessment (MA MA 2005), United Kingdom National Ecosystem Assessment (UK NEA 2011), and Strategic Environmental Assessment of Hydropower on the Mekong Mainstream (ICEM 2010). 
An example of ongoing assessment considering plausible future scenarios and their impacts on biodiversity, ES, and human well-being is PANCES (Predicting and Assessing Natural Capital and Ecosystem Services) through an Integrated Social-Ecological Systems Approach project (PANCES 2017). This is a 5-year research project to predict and assess the natural capitals and ES in Japan. As part of the PANCES project, national-scale future scenarios for exploring potential changes in the natural capitals and ES as well as human well-being were developed up to 2050 considering any significant direct and indirect drivers (Saito et al. 2018). On the basis of the Delphi survey and discussion with researchers and policymakers participating in the PANCES project, two drivers for scenario axes were identified: (1) Will future society go in the direction of the "natural capital base" that promotes ecosystem-based infrastructure development and land management, or will it change to the "produced capital base" that depends more on manmade infrastructures and technologies? (2) Will the population concentration advance to promote "urban compaction" in compact cities that hold large populations while rewilding or greening underutilized land, or will the population concentration lessen and lead to a decentralized society with a "dispersed population" that maintains rural communities? Natural capital can be defined as everything in nature (biotic and abiotic) that is capable of providing human beings with various ecosystem services, either directly or through production processes, while traditional definition of produced capital is capital of human/industrial elements presupposing natural capitals including roads, buildings, ports, machinery, equipment, and technologies (Jamieson 1998; Saito et al. 2018; Schaubroeck 2018). According to these two axes, four future scenarios were created: "natural capital-based compact society," "natural capital-based dispersed society," "produced capital-based compact society," and "produced capital-based dispersed society."

The PANCES scenarios were designed by researchers and policymakers, thus the public perception was not taken into account (Saito et al. 2018). Oteros-Rozas et al. (2015) stated that involving diverse stakeholders with influence and interest in the social-ecological system, including those potentially most affected, might foster social learning and collective action to achieve the desired goals. Similarly, IPBES pointed out that the scientific community, policymakers, and stakeholders might want to consider improving, and more widely applying, participatory scenario methods to enhance the relevance and acceptance of scenarios for biodiversity and ES (IPBES 2016).

Especially, it is meaningful to understand and reflect preferences or perception of general public, the basic stakeholders of social transformation, for the axes of scenarios. As Kowalski et al. (2009) and Tanaka et al. (2014) conducted similar process to examine scenarios; the PANCES project also reached a step where the preferences of the general public are required to reflect the scenarios.

This study, therefore, focused on the preferences of the Japanese people in one of the key axes of PANCES scenarios, i.e., natural capital-basis or produced capital-basis. Goklany (2009), Fitter (2013), and Schaubroeck (2018) argued that there are various ES including solutions to sustainability issues whose dependence on natural capitals and produced capitals were different. A pure natural capitalbased ES is completely based on elements and direct inputs from natural capital, thus not containing any produced capital such as the carbon sequestration by the untouched rainforest, while produced capital-based ES is one only based on produced capitals (Schaubroeck 2018). However, many types of ES are based on both natural and produced capital in various levels. For example, wild vegetables are derived from natural capitals such as forests, whereas vegetables produced at plant factories originate from produced capitals such as advanced plantation technologies. The middle ground of these examples is outdoor vegetable cultivation, which is a mixture of a natural capital (natural nutrient cycle) and a produced capital (intervention by humans or agricultural machinery). In other words, humans can utilize diverse ES which natural capitals and produced capitals provide while complementing and balancing variously. Therefore, this study investigated the preferences in ES consisting of the different extent of natural capitals and produced capitals but with the same contribution for humans. The study was conducted by distributing questionnaires targeting people belonging to various generations and living in both the urban and rural areas of Japan.

\section{Materials and methods}

\section{Study site}

To investigate the preferences toward natural or -produced capital-based ES of the Japanese with different attributes, this study was conducted in two different areas of Japan. Tokyo and Nanao city of Ishikawa prefecture (Fig. 1) were selected as representative of the urban area and the rural area, respectively.

Tokyo is the capital and located in the eastern part of the main island of Japan. Tokyo, a metropolitan city (Kearney 2017), accounts for the largest share of population and economic activity in Japan (Ministry of Land, Infrastructure, Transport and Tourism 2018). Approximately 9.5 million people live in $57.7 \%$ of Tokyo's total area (23 wards of 62,853 ha); however, areas for parks, agricultural land, and forests are limited to $6.4 \%, 1.0 \%$, and $0.1 \%$, respectively (Bureau of General Affairs of Tokyo Metropolitan Government 2018; Bureau of Urban Development of Tokyo 
Fig. 1 Location of Tokyo's wards area and Nanao city of Ishikawa prefecture

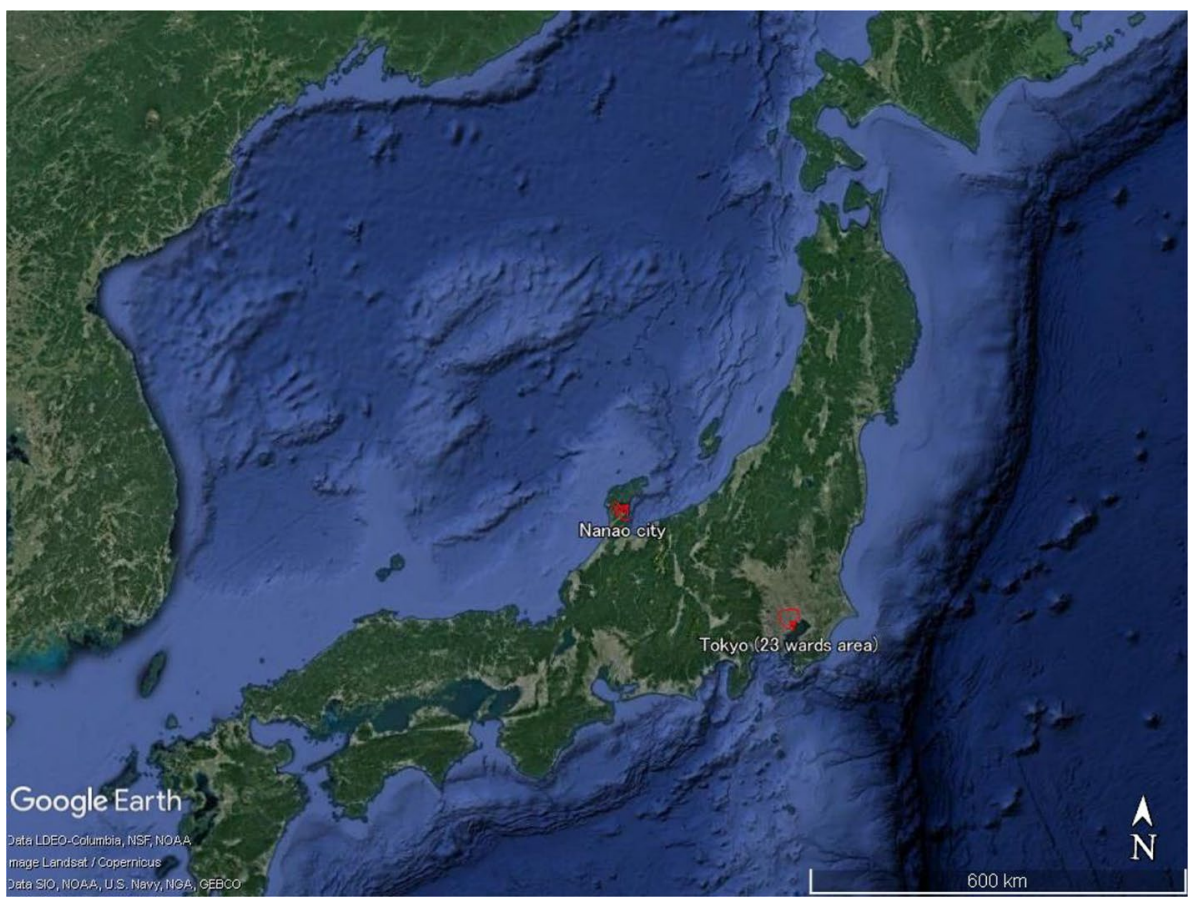

Metropolitan Government 2011). Respondents to this questionnaire survey were students of one high school and their families in each study site. Nerima ward where the targeted high school of Tokyo is located holds the largest area of farmland among Tokyo 23 wards (Bureau of Urban Development of Tokyo Metropolitan Government 2011). Due to the municipality policy of Nerima ward to conserve productive green zones (Nerima city office 2018), the residents and students of Nerima have opportunity to access and appreciate natural capital-based ES, although their availability and access frequency may be less than those in rural areas outside of Tokyo.

Nanao city is a central city of Noto Peninsula facing the Sea of Japan and belongs to Ishikawa prefecture located in the middle of Japan's main island. Noto Peninsula was the first area selected by the Food and Agriculture Organization of the United Nations (FAO) as a Globally Important Agricultural Heritage System (GIAHS) in Japan (FAO 2018). Noto is characterized by a mosaic of different ecosystem types such as secondary forests, farmlands, irrigation ponds, and grasslands along with human settlements, referred to as Satoyama (JSSA 2010), and by marine-coastal ecosystems comprising seashore, rocky shore, tidal flats, and seaweed/ eelgrass beds, referred to as Satoumi (FAO 2018). The areas of building lots, agricultural land, and forests (and fields) are $9.1 \%, 32.3 \%$, and $56.6 \%$ of Nanao city's total area (31,832 ha), respectively (Nanao city 2016). Fifty-three thousand residents of Nanao city live and work together to sustainably maintain the Satoyama and Satoumi landscapes as well as preserve their traditions (FAO 2018).

\section{Surveyed ES}

18 types of ES were selected from previous studies and pre-surveys (Japan Biodiversity Outlook Science Committee 2015). Table 1 shows the surveyed ES, each with two options of being from natural capitals or produced capitals. The sources (i.e., previous studies or pre-surveys) of the chosen surveyed ES were also included.

Fitter (2013) listed 19 technologies that could replace or enhance ES. ES were classified into three categories: supporting services, final services, and goods. Goklany (2009) identified some possible technologies for the $19 \mathrm{ES}$ that were categorized into provisioning, regulating, and cultural services, and concluded that there were numerous technological options for replacing or extending ES. As a pre-survey, preferences for the natural capitals and the produced capitals for $13 \mathrm{ES}$ were investigated in a webbased survey in 2015 targeting more than 3000 respondents living in Japan (Saito et al. 2015). The surveyed 13 ES were selected by literature review of Japanese reports and journals. Although surveyed 13 ES covered all four categories, many of questions were related to food supply.

Among the listed ES in the above-mentioned previous research and pre-survey, 18 were selected and are shown in Table 1. The selection considered the ES and alternatives that were imaginable and relevant for respondents in Japan and the balance of ES types. For example, questions on disease regulation in agriculture and forestry by biocides or on biological controls such as plant mixtures (Fitter 
Table 1 Surveyed ES and their sources

\begin{tabular}{|c|c|c|c|c|c|c|}
\hline No. & $\begin{array}{l}\text { Ecosystem services based on more } \\
\text { natural capitals }\end{array}$ & $\begin{array}{l}\text { Ecosystem services based on more } \\
\text { produced capitals }\end{array}$ & Category & Pre-survey & Fitter (2013) & Goklany (2009) \\
\hline 1 & $\begin{array}{l}\text { Eat rice grown by traditional way such } \\
\text { as drying rice on racks }\end{array}$ & $\begin{array}{l}\text { Eat rice grown with enhanced opera- } \\
\text { tion efficiency by such as harvesting } \\
\text { machines or drying machine }\end{array}$ & Provisioning & O & & \\
\hline 2 & $\begin{array}{l}\text { Eat crops grown at home or grown by } \\
\text { acquaintances }\end{array}$ & Eat crops purchased from markets & Provisioning & O & & \\
\hline 3 & Eat domestic local foods & Eat imported foods & Provisioning & O & & \\
\hline 4 & Eat natural fish & Eat cultured fish & Provisioning & O & & O \\
\hline 5 & Drink tap water & Drink bottled water & Provisioning & O & & \\
\hline 6 & $\begin{array}{l}\text { Wear clothes made of natural fibers } \\
\text { (silk, cotton, linen etc.) }\end{array}$ & $\begin{array}{l}\text { Wear clothes made of synthetic fibers } \\
\text { (nylon, polyester etc.) }\end{array}$ & Provisioning & & $\bigcirc$ & O \\
\hline 7 & $\begin{array}{l}\text { Eat NTFPs such as mushrooms and } \\
\text { wild vegetables picked up from } \\
\text { forests at a certain season }\end{array}$ & $\begin{array}{l}\text { Eat NTFPs such as mushrooms and } \\
\text { wild vegetables grown for markets at } \\
\text { all season }\end{array}$ & Provisioning & & & O \\
\hline 8 & $\begin{array}{l}\text { Eat dishes made at home from ingre- } \\
\text { dients }\end{array}$ & $\begin{array}{l}\text { Eat ready-made dishes made at facto- } \\
\text { ries, markets, and convenience stores }\end{array}$ & Provisioning & O & & \\
\hline 9 & Increase $\mathrm{CO}_{2}$ sinks by plantation & $\begin{array}{l}\text { Capture } \mathrm{CO}_{2} \text { artificially and storage in } \\
\text { the ground }\end{array}$ & Regulating & $\bigcirc$ & O & O \\
\hline 10 & $\begin{array}{l}\text { Purify air by maintained forest and } \\
\text { green spaces }\end{array}$ & $\begin{array}{l}\text { Purify air by machines such as air } \\
\text { cleaners }\end{array}$ & Regulating & O & & O \\
\hline 11 & $\begin{array}{l}\text { Control floods by forests and flood } \\
\text { plains }\end{array}$ & Control floods by dams and floodways & Regulating & $\bigcirc$ & & O \\
\hline 12 & Eat crops of pest-resistant species & $\begin{array}{l}\text { Eat crops grown with chemical } \\
\text { fertilizers }\end{array}$ & Regulating & O & ○ & O \\
\hline 13 & $\begin{array}{l}\text { Cool off by breeze or in the shade of } \\
\text { trees }\end{array}$ & Cool off by air conditioners & Regulating & O & & \\
\hline 14 & $\begin{array}{l}\text { Eat fruits and vegetables fruited by } \\
\text { pollination via wild insects }\end{array}$ & $\begin{array}{l}\text { Eat fruits and vegetables fruited by } \\
\text { artificial pollination via collected } \\
\text { insects, machines, and humans }\end{array}$ & Regulating & & O & O \\
\hline 15 & $\begin{array}{l}\text { Observe animals and plants living in } \\
\text { nature }\end{array}$ & $\begin{array}{l}\text { Observe animals and plants living in } \\
\text { artificial environment such as zoos } \\
\text { or botanical gardens }\end{array}$ & Supporting & O & & O \\
\hline 16 & $\begin{array}{l}\text { Obtain knowledge for life from local } \\
\text { old people }\end{array}$ & Obtain knowledge from internet & Cultural & $\bigcirc$ & & \\
\hline 17 & $\begin{array}{l}\text { Trek, swim, and gaze stars in the real } \\
\text { nature }\end{array}$ & $\begin{array}{l}\text { Experience virtual nature in such as } \\
\text { theme parks and planetariums }\end{array}$ & Cultural & $\bigcirc$ & & O \\
\hline 18 & Feel sacredness from real nature & $\begin{array}{l}\text { Feel sacredness of nature from videos } \\
\text { or photos }\end{array}$ & Cultural & $\bigcirc$ & & O \\
\hline
\end{tabular}

NTFPs: non-timber forest products

2013) were excluded because most Japanese respondents would find these hard to answer because of unfamiliarity.

It should be noted that the selected questions included those comparing the processes to obtain such services. For example, Q3 assumed that longer supply chains were more dependent on human transport, and Q16 perceived the process of obtaining knowledge via the internet is more reliant on produced capital compared to being through word of mouth. In regard to Q5, it was assumed that bottled water delivery system in Japan depend on produced capitals more than tap water due to relying on technology-based processes such as production of bottles (Miki et al. 2010).

\section{Details of the questionnaire survey and analysis}

Questionnaires were distributed to high school students and their families in each study site to investigate the current preferences toward natural and produced capital-based ES by ages (Supplementary Appendix). With regard to the survey conducted in Tokyo in 2016, 436 high school students and their families were requested to answer the questionnaires; one student answered by himself and took home two more questionnaires for his family. The same survey was carried out with 159 high school students and their families in Nanao city in 2015 . In total, 592 and 420 questionnaire samples 
were collected in Tokyo and Nanao city, respectively. The survey consisted of questions that outlined the attributes of the respondents such as sex, age, number of family members, residence years, and residential area (Table 2). The number of male respondents was more than that of female respondents. A large number of respondents were under 20 years, the age group to which high school students and their families such as siblings belong, and 40-59 years, the age group to which their parents belong. The respondents in Nanao city tended to have more family members and longer residence years than those in Tokyo.

On the questionnaires, ES in Table 1 were divided into natural capital-based and produced capital based and listed in column $\mathrm{A}$ and $\mathrm{B}$, and rated on a five-point scale as follows: $1=$ choose $\mathrm{A}, 2=$ tend to choose $\mathrm{A}, 3=$ neither, $4=$ tend to choose B, $5=$ choose B (Supplementary Appendix). To improve a problem of pre-survey, natural capital

Table 2 Attributes of the respondents and the corresponding numbers for each attribute

\begin{tabular}{|c|c|c|c|}
\hline & Tokyo & Nanao & Total \\
\hline \multicolumn{4}{|l|}{ Sex } \\
\hline Male & 462 & 165 & 627 \\
\hline Female & 128 & 253 & 381 \\
\hline Non-response & 2 & 2 & 4 \\
\hline \multicolumn{4}{|l|}{ Age } \\
\hline Under 20 & 444 & 174 & 618 \\
\hline $20-39$ & 4 & 15 & 19 \\
\hline $40-59$ & 133 & 174 & 307 \\
\hline $60-79$ & 5 & 49 & 54 \\
\hline Over 80 & 2 & 6 & 8 \\
\hline Non-response & 4 & 2 & 6 \\
\hline \multicolumn{4}{|c|}{ The number of family members (excluding respondents) } \\
\hline 0 & 2 & 1 & 3 \\
\hline 1 & 10 & 4 & 14 \\
\hline 2 & 34 & 30 & 64 \\
\hline 3 & 158 & 77 & 235 \\
\hline 4 & 297 & 113 & 410 \\
\hline 5 & 60 & 88 & 148 \\
\hline Over 5 & 21 & 105 & 126 \\
\hline Non-response & 10 & 2 & 12 \\
\hline \multicolumn{4}{|l|}{ Residence year } \\
\hline Under 10 & 227 & 61 & 288 \\
\hline $10-19$ & 322 & 205 & 527 \\
\hline $20-29$ & 10 & 61 & 71 \\
\hline $30-39$ & 2 & 13 & 15 \\
\hline $40-49$ & 3 & 27 & 30 \\
\hline $50-59$ & 1 & 22 & 23 \\
\hline Over 60 & 1 & 11 & 12 \\
\hline Non-response & 26 & 20 & 46 \\
\hline Total numbers of respondents & 592 & 420 & 1012 \\
\hline
\end{tabular}

and produced capital based ES were sorted into A and B randomly. The respondents were asked to assume that ES based on both natural and produced capitals were available.

On the basis of the results of the questionnaires, the correlation between preferential tendency toward natural and produced capitals and individual attributes of respondents was analyzed. An ordered logistic regression was used for analysis adopting answered preferences and the five types of attributes as objective variables and explanatory variables, respectively. The answered preferences were converted to five-point scale as follows: $1=$ choose natural capital-based, $2=$ tend to choose natural capital-based, $3=$ neither, $4=$ tend to choose produced capital-based, $5=$ choose produced capital-based. The individual attributes of sex $($ male $=1$, female $=0)$ and residential area $($ Tokyo $=1$, Nanao $=0)$ were used as categorical variables. With regard to age, number of family members, and residential years, the answered numbers were used as variables. This analysis was implemented using the Cumulative Link Model built in the package "ordinal” for the R software (Christensen 2018).

\section{Results}

The statistical dispersions of the answered results are shown as box plots in Fig. 2. As a general trend, the number of ES whose natural capital-based option was preferred was higher than that whose produced capital-based option was preferred. The preferences for rice cultivation (Q1), origins of crops (Q2), water purification (Q5), and ways of cooling off (Q13) were partial neither to natural nor produced capitals. Non-timber forest products (NTFPs) that were grown for markets (Q7) tended to be selected more than NTFPs that were picked up from forests. People also preferred obtaining knowledge from the internet than from older people (Q16). In other ES, natural capital-based options had higher tendencies to be chosen than produced capital-based options.

Table 3 shows the results of the ordered logistic regression analysis. The listed numbers were the estimated coefficients of each explanatory variable for each preference of ES. The correlation coefficients between the five explanatory variables were less than 0.6; thus, all the five attributes were used for an ordered logistic regression analysis with the judgment of no multicollinearity. Additionally, it was shown that residential area, sex, age, and residence years affected some of the preferences in ES differently. The attributes affected significantly to preferences of each questions were marked by asterisks.

Based on the results shown in Table 3, Figs. 3 and 4 show the statistical dispersions of the preferences in ES that were significantly affected by sex and residential area, respectively. With regard to how the sex attribute affected the ES preference (Fig. 3), male respondents leaned toward 
Natural capital-based

Q1. Rice grown by

Q2. Crops

Q3. Foods

Q4. Fish

Q5. Water

Q6. Fibers

Q7. NTFPs

Q8. Dish

Q9. $\mathrm{CO}_{2}$

Q10. Air purification by

Q11. Flood control by

Q12. Crops

Q13. Cool off by

Q14. Foods fruited by

Q15. Observe animals and plants live in nature

Q16. Obtain knowledge from

Q17. Recreation in

Q18. Feel sacredness from traditional way

grown at home

domestic

natural

tap

natural (silk, cotton etc.) 。

pickedup from forests

home-made

absorption by plantation

forests

forests

of pest-resistant species

breeze

natural pollination

local old people

real nature
Produced capital-based

† modern technologies

purchased from markets

- imported

cultured

bottled

artificial (nylon etc.)

grown for markets

ready-made

sequestration technologies

machines

- dams

- by chemical fertilizers

air conditioners

artificial pollination

zoos / botanical gardens

internet

virtual nature or gym

videos or photos

Fig. 2 Box plots showing statistical dispersions of the questionnaires answers

produced capital-based options such as imported foods (Q3), flood control by dams (Q11), sacredness from videos and photos compared with female. It was observed that only one ES based on produced capital which female respondents prefer than men was bottled water. According to an internet survey on public attitudes toward science and technology conducted by Ataka et al. (2008) in Japan, the ratio of men thinking that science improved the world was more than that of women. The different notions about science and technology between males and females were reflected in the different preferences toward produced capital-based options. On the other hand, the preference for bottled water in women was thought to be caused by a higher perception about the risk of tap water. Among a part of Japanese, tap water is recognized to be at healthy risk by harmful substance derived from chlorination, thus the usage of water purifiers or consumption of bottled water have spread. As Amano et al. (2013) demonstrated, females tend to perceive the risk of tap water higher than males. It is considered as a reason why women prefer bottled water strongly compared to men although bottled water depend on produced capitals more than tap water.

Residential area, especially for those living in Tokyo, significantly contributed to the preferences toward produced capital-based ES such as crops purchased from markets $(\mathrm{Q} 2)$, bottled water $(\mathrm{Q} 5)$, cultured fish $(\mathrm{Q} 4)$, and obtaining knowledge via the internet (Q16), as shown in Fig. 4. The possible cause for these differences was the decoupling of people from nature especially in areas under urbanization (Huckauf 2008). The love for nature is argued to be innate (called Biophilia, Wilson 1984) and also learned and experiential (Simaika et al. 2010). It means that experiences to interact with nature are also necessary to enhance affinity for natural capitals as Wells et al. (2006) revealed by examining the contribution of nature experiences to environmental attitudes. Therefore, the limited nature experiences in urban areas can be considered as a cause of weaker preference to natural capital-based ES compared to in rural areas.

In regards to Q16, according to previous studies, knowledge handed down from old people traditionally is developed with being adopted to the local culture and environment and is mainly of a practical nature, particularly in such fields as agriculture, fisheries, health, horticulture, forestry and environmental management (Secretariat of the Convention on Biological Diversity 2002). In addition, such types of knowledge are about the relationship of living beings (including humans) with their environment (Díaz et al. 2015) and are valuable in terms of determination of the coviability of social and ecosystem dynamics and the design of people-centered resource management approaches (Cetinkaya 2009). Therefore, there is a possibility that the direct needs for such traditional knowledge are stronger in local 
Table 3 Results of the estimated coefficients of the ordered logistic regression analysis

\begin{tabular}{|c|c|c|c|c|c|c|c|}
\hline Question & $\begin{array}{l}\text { Q1.Rice grown by mod- } \\
\text { ern technologies (vs. } \\
\text { traditional way) }\end{array}$ & $\begin{array}{l}\mathrm{Q} 2 . \mathrm{Cr} \\
\text { from } n \\
\text { grown }\end{array}$ & $\begin{array}{l}\text { ops purchased } \\
\text { larkets (vs. } \\
\text { at home) }\end{array}$ & $\begin{array}{l}\text { Q3.Foods } \\
\text { domestic) }\end{array}$ & imported (vs. & $\begin{array}{l}\text { Q4.Fish cultured (vs. } \\
\text { natural) }\end{array}$ & $\begin{array}{l}\text { QS.Water bottled (vs. } \\
\text { top) }\end{array}$ \\
\hline Area & 0.15 & 0.77 & $* * *$ & $0.27^{\dagger}$ & & $0.37 *$ & $0.38 * *$ \\
\hline Sex & -0.11 & 0.19 & & $0.45^{* *}$ & & 0.02 & $-0.33 *$ \\
\hline Age & $-0.01^{\dagger}$ & -0.01 & & $-0.01^{\dagger}$ & & $-0.01 * *$ & 0.00 \\
\hline Family & 0.00 & -0.01 & & 0.02 & & 0.01 & $-0.07^{\dagger}$ \\
\hline Residence years & 0.00 & 0.00 & & 0.00 & & 0.00 & 0.00 \\
\hline Question & $\begin{array}{l}\text { Q6.Fibers artificial (vs. } \\
\text { natural) }\end{array}$ & $\begin{array}{l}\text { Q7.NT } \\
\text { market } \\
\text { from fo }\end{array}$ & $\begin{array}{l}\text { FPS grown for } \\
\text { (vs. picked up } \\
\text { rests) }\end{array}$ & $\begin{array}{l}\text { Q8.Dislis } r \\
\text { (vs. home- } n\end{array}$ & $\begin{array}{l}\text { eady-made } \\
\text { nade) }\end{array}$ & $\begin{array}{l}\mathrm{Q} 9 . \mathrm{CO}_{2} \text { sequestration } \\
\text { by technologies (vs. } \\
\text { absorption by planta- } \\
\text { tion) }\end{array}$ & $\begin{array}{l}\text { Q10.Air purification by } \\
\text { machines (vs. forests) }\end{array}$ \\
\hline Area & -0.01 & $0.28^{\dagger}$ & & -0.13 & & 0.23 & 0.10 \\
\hline Sex & 0.14 & -0.09 & & $0.50 * * *$ & & 0.20 & $0.29^{\dagger}$ \\
\hline Age & $-0.03 * * *$ & -0.01 & & $-0.01 *$ & & 0.00 & $-0.01^{*}$ \\
\hline Family & 0.01 & -0.01 & & 0.01 & & 0.02 & $0.05^{\dagger}$ \\
\hline Residence years & $0.02 * * *$ & -0.01 & & -0.01 & & 0.00 & $-0.01^{\dagger}$ \\
\hline Question & $\begin{array}{l}\text { Q11.Flood control by } \\
\text { dams (vs. forests) }\end{array}$ & $\begin{array}{l}\text { Q12.Cr } \\
\text { calfert } \\
\text { pest-re. }\end{array}$ & $\begin{array}{l}\text { ops with chemi- } \\
\text { ilizer (vs. of } \\
\text { istant species) }\end{array}$ & $\begin{array}{l}\text { Q13.Cool o } \\
\text { conditioner } \\
\text { breeze })\end{array}$ & $\begin{array}{l}\text { ff by air } \\
s \text { (vs. }\end{array}$ & $\begin{array}{l}\text { Q14.Foods fruitd by } \\
\text { artificial pollination } \\
\text { (vs. natural pollina- } \\
\text { tion) }\end{array}$ & $\begin{array}{l}\text { Q15.Animals and plants } \\
\text { live in zoos/botanical } \\
\text { gardens (vs. nature) }\end{array}$ \\
\hline Area & -0.03 & 0.10 & & 0.18 & & $0.42 * *$ & 0.03 \\
\hline Sex & $0.32 *$ & 0.19 & & 0.09 & & $0.34 *$ & 0.22 \\
\hline Age & 0.00 & 0.00 & & $-0.02 * * *$ & & $-0.01^{\dagger}$ & $-0.01 * *$ \\
\hline Family & 0.00 & $0.07^{\dagger}$ & & 0.02 & & 0.02 & 0.00 \\
\hline Residence years & -0.01 & -0.01 & & $-0.01^{\dagger}$ & & -0.01 & 0.00 \\
\hline Question & $\begin{array}{l}\text { Q16.Obtain knowled } \\
\text { from internet (vs. loc } \\
\text { people) }\end{array}$ & $\begin{array}{l}\text { lge } \\
\text { cal old }\end{array}$ & $\begin{array}{l}\text { Q17.Recreation } \\
\text { nature (vs. the r }\end{array}$ & $\begin{array}{l}\text { in virtual } \\
\text { eal nature) }\end{array}$ & $\begin{array}{l}\text { Q18. Feel sac } \\
\text { videos or pho } \\
\text { nature) }\end{array}$ & $\begin{array}{l}\text { credness from } \\
\text { otos (vs. real }\end{array}$ & \\
\hline Area & $0.47 * *$ & & -0.06 & & 0.01 & & \\
\hline Sex & $0.37 *$ & & $0.26^{\dagger}$ & & $0.38^{*}$ & & \\
\hline Age & $-0.01 * *$ & & 0.00 & & $-0.01 *$ & & \\
\hline Family & -0.01 & & 0.00 & & 0.00 & & \\
\hline Residence years & $-0.02 * *$ & & $-0.02 *$ & & 0.00 & & \\
\hline
\end{tabular}

$* * * \operatorname{Pr}<0.001, * * \operatorname{Pr}<0.01, * \operatorname{Pr}<0.05,{ }^{\dagger} \operatorname{Pr}<0.1$

areas close to nature and primary industry than urban areas. It is also considered as a cause of preferential tendency for knowledge from old people by respondents from Nanao city.

Figures 5 and 6 describe the preferential distribution of ES significantly contributed by age and residence years, respectively. Regression lines are inserted into Figs. 5 and 6 to help indicate the trends. The results showed that the preference for some natural capital-based ES became stronger as age increased and as the residence years became longer. With respect to age, the trends were notably observed in ES such as crops grown at home (Q2), natural fibers (Q6), cooling off by breeze (Q13), and obtaining knowledge from old people (Q16) (Fig. 5). There was a possibility that experience gaps caused the preferential change. Generally, technological development to replace and/or complement nature is a major global trend. Several electric appliances such as air conditioners and televisions came to be used widely in these 60 years in Japan (Ministry of Land, Infrastructure, Transport and Tourism 2012), it means older respondents have had more experiences of utilizing natural capital-based ES. This is the reason why there was a higher preference for natural capital-based ES by age.

Residential years contributed to the preferences of respondents for gaining knowledge from older people (Q16) (Fig. 6). The results were thought to reflect the reality that residents who had not lived in the area long enough certainly had limited accessibility to, and a limited perception of, local social capital, for example, estranged neighbors who could 


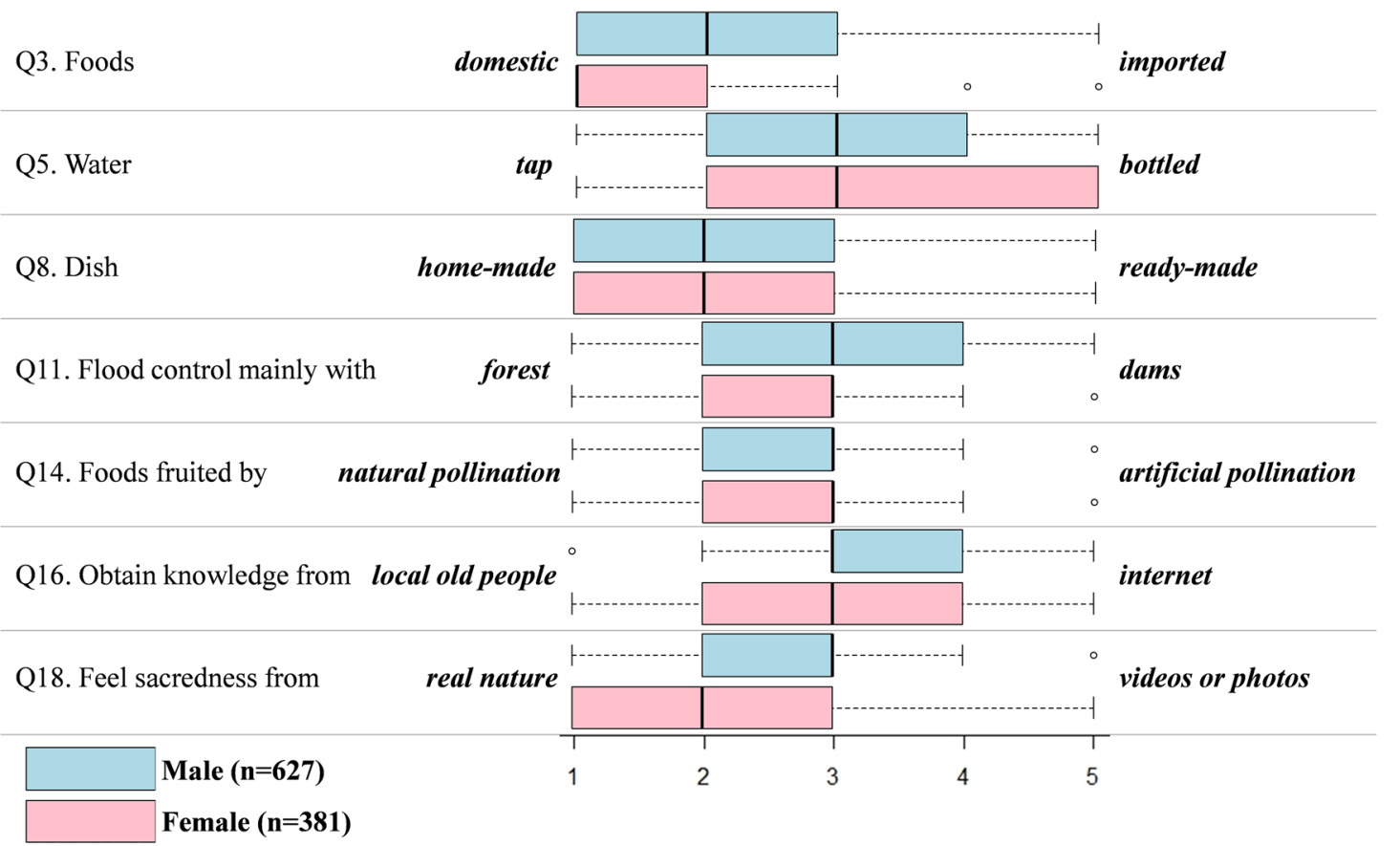

Fig. 3 Box plots of ES preferences significantly affected by sex

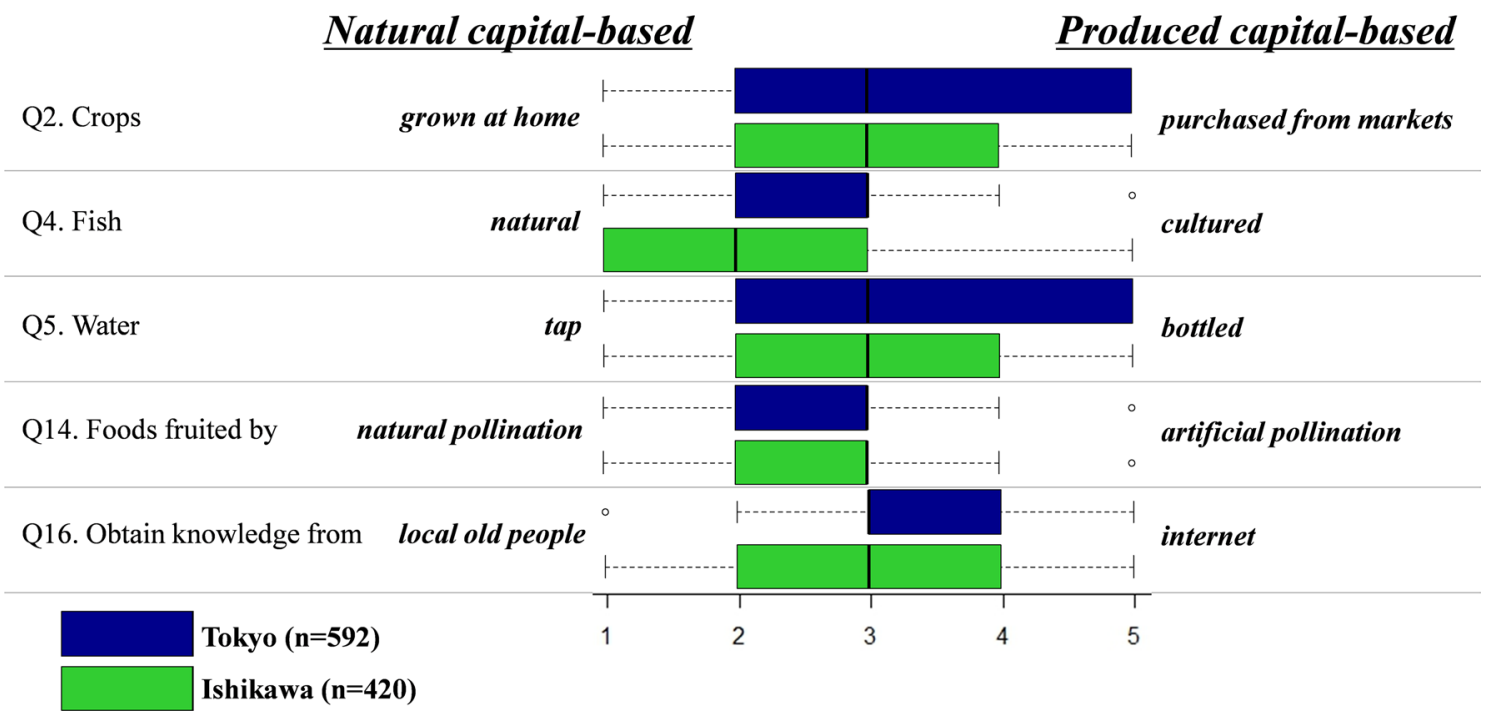

Fig. 4 Box plots of ES preferences significantly affected by residential area

have informed them. The preferences of obtaining knowledge from older people were also negatively affected by the place of residence, whether in Tokyo or not. In Japan, it was reported that the attenuation of social relations in the local community was an important issue in urban areas (Ministry of Internal Affairs and Communications 2014). Less access to social capital and to traditional knowledge of the rural community in the urban area was deemed a cause of this correlation. 


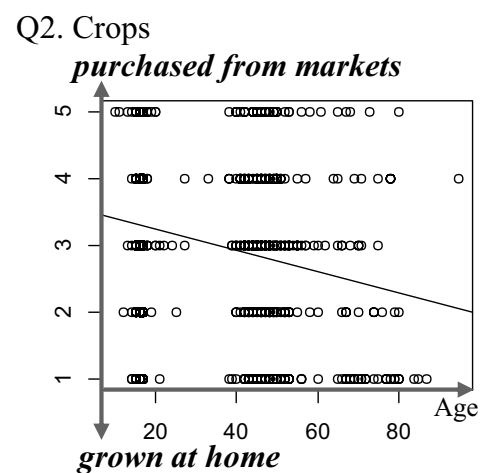

Q8. Dishes

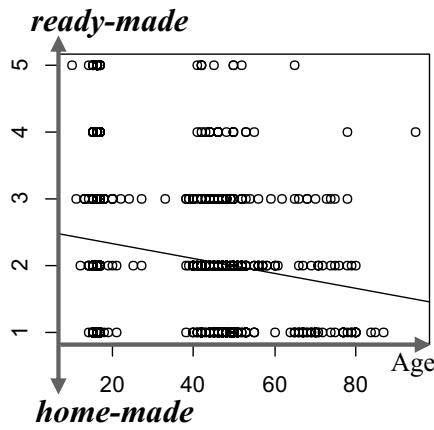

Q15. Animals and plants live in

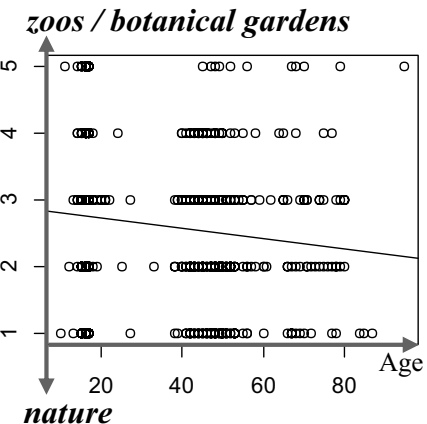

Q4. Fish

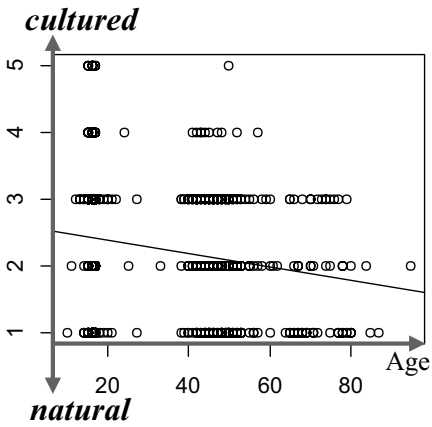

Q10. Air purification by

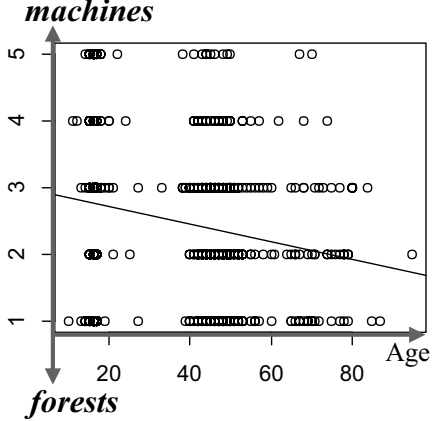

Q16. Obtain knowledge from

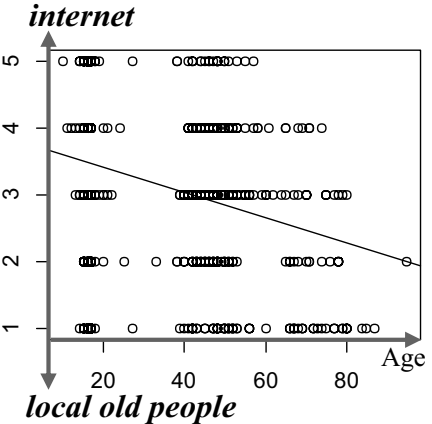

Q6. Fibers

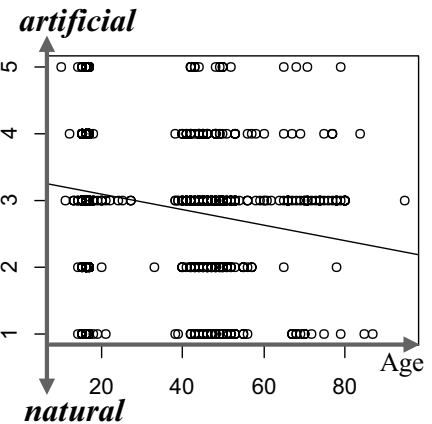

Q13. Cool off by

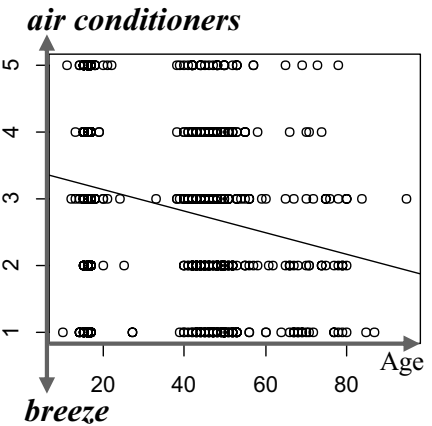

Q18. Feel sacredness from

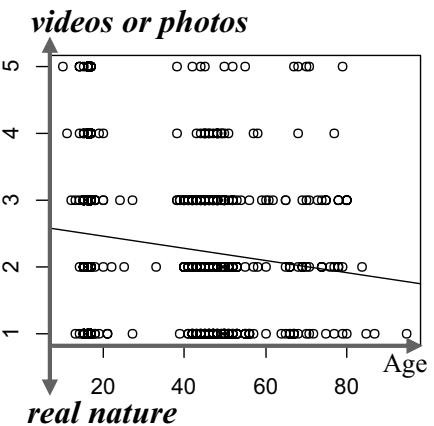

Fig. 5 Correlation between age and ES preferences significantly affected by age (under $20, n=618 ; 20-39, n=19 ; 40-59, n=307 ; 60-79$, $n=54$; Over $80, n=8$ )

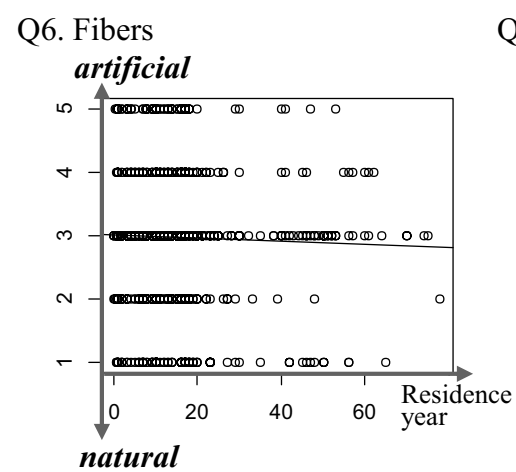

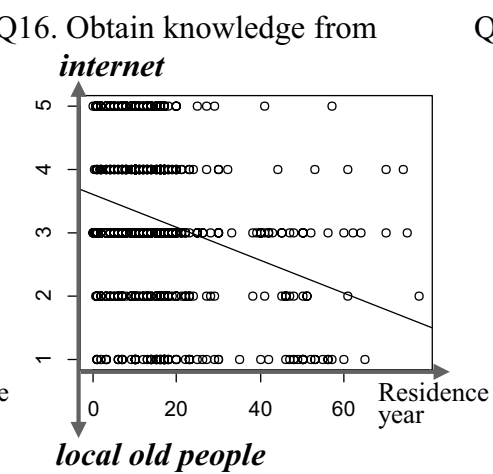

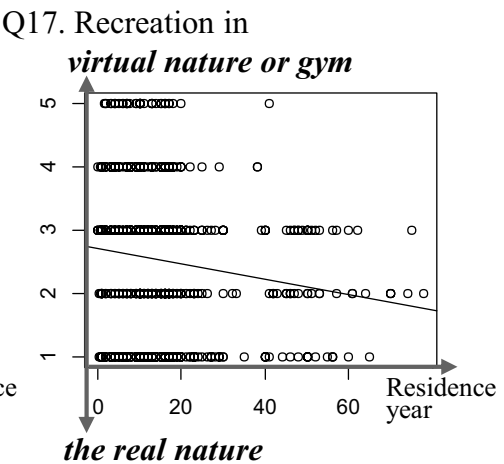

Fig. 6 Correlation between residential year and ES preferences significantly affected by residential year (under 10, $n=288 ; 10-20 \mathrm{~s}, n=527$; $20-30 \mathrm{~s}, n=71 ; 30-40 \mathrm{~s}, n=15 ; 40-50 \mathrm{~s}, n=30 ; 50-60 \mathrm{~s}, n=23$; Over $60, n=12$ ) 


\section{Discussion}

The results indicated a general tendency toward a stronger preference for natural capital-based ES, and these preferences were affected by the attributes of the respondents. It proved that humans could enhance their well-being by appreciating ES from natural capitals, despite the expansion of produced capital-based ES. However, it was observed that ES served in areas away from the natural capitals such as cities tended to rely on the produced capitals; thus, it is necessary to create opportunities that allow people to enjoy natural capital-based ES no matter where they live.

The fact that natural capital-based ES were preferred possibly means that the produced capitals such as technologies could not replace the natural capitals completely. It is safe to say that produced capitals would only complement natural capitals. The complementary relationship between natural capitals and human-produced capitals has been argued over the last few decades (Daly 1995; Jamieson 1998). As a deeply related controversy, the debate of "weak sustainability" based on "substitutability paradigm" of natural and produced capitals versus "strong sustainability" based on "non-substitutability paradigm" has been developed (Neumayer 2003). The produced capitals could be viewed as the transforming agent for the natural capitals into products. For example, some tools (i.e., produced capitals) are necessary to hunt wild animals for human food. In other words, the appreciation of ES requires both natural and produced capitals (Costanza et al. 2014). Honey-Rosés et al. (2014) attempted to show through a case study that even if sophisticated technology had been installed to replace the ecosystem functions, natural capitals would remain complementary to the technological change. Fitter (2013) distinguished between replacement and enhancement by technologies and between displacement and supplementation of ES. Goklany (2009) argued that technology may occasionally substitute ES completely, but, more often or not, it may augment their production. These arguments prevent falling into the bipolar logic such as which of natural capital-based or produced capital based ES should be chosen. The results of our study can be said to substantiate the complementary relationship of natural and produced capitals supporting the concept of "strong sustainability".

Among the surveyed ES, regulating services by functions of the forests such as $\mathrm{CO}_{2}$ absorption or air purification (Q9-Q12) and cultural services in nature (Q17 and Q18) were preferred. Distribution systems such as the internet or market were preferred among the produced capital-based ES options (Q2, Q7, and Q16). These findings were possibly useful in elaborating the storylines of the PANCES scenarios. The existing storylines of ES utilization in each
PANCES scenario have not been fully elaborated in detail enough such as "use of ecosystem-based green infrastructures" or "extensive use of ICT/AI for improved productivity" (Saito et al. 2018). The results of this study can be used to enrich the storylines of PANCES scenarios by identifying specific types of ES likely to be utilized more in each scenario. Based on our study, for example, in natural capitalbased society, its scenario storyline should consider more opportunities to utilize the function of forests and to enjoy the cultural services from nature, while produced capitalbased society's storyline should contain further advancement in technologies to fulfill people's daily necessities.

The stronger preference toward natural capital-based ES suggested that the general public possibly preferred natural capital-based scenarios than produced capital-based scenarios in the PANCES project. In addition, the contrasting results of Tokyo and Nanao city residents could be interpreted to incorporate other axes, namely "urban compaction" and "dispersed population." The respondents from Tokyo and Nanao city were simulated residents of the compacted urban area and the dispersed rural area, respectively. The preference toward produced capital-based ES was stronger among residents from Tokyo than from Nanao city. This result implied that the compacted urban area had a higher affinity toward produced capital-based ES, whereas the dispersed rural area had a higher affinity toward natural capitalbased ES. In other words, "natural capital-based dispersed society" and "produced capital-based compact society" may be more plausible than the others among PANCES scenarios.

It should be noted, however, that "natural capital-based compact society" and "produced capital-based dispersed society" will be plausible to some extent if the likelihood is not the same. For examples, as movements promoting natural capital-based compact society, the research on greenspace planning in cities (Haaland and van den Bosch 2015) and on urban agriculture at such as rooftop gardens (Specht et al. 2014) have been increasingly conducted. As the signs toward produced capital-based dispersed society, 100 cases of development of rural areas utilizing ICT (Information and Communication Technology) and IoT (Internet of Things) are reported by Ministry of Internal Affairs and Communications, Japan (Ministry of Internal Affairs and Communications 2018).

The limitations of this study include the limited number of respondents and sampling method. The questionnaire survey was conducted in only two areas in Japan targeting high school students and their families. Therefore, the respondents represented generations under 20 and 40-59 years old. There is a possibility that the pattern of preference were similar among members of the same family, which implies that this study's samples were not completely independent. The study focused on preference of current ES rather than the preference change over time toward future. Therefore, 
extended research at larger spatial scale by random sampling should be considered as future work, with explicit consideration of future change of ES use.

In addition, the respondents of this study were requested to state their preferences with the assumption that both natural and produced capital-based ES were available in their daily lives. It should be noted that the answered preferences were not necessarily equal to the actual choice by the respondents. Especially the different costs to utilize each ES and the real availability of each capital-based ES might affect the actual choice. As Honey-Rosés et al. (2014) pointed out, the key incentive for improving and utilizing the ecosystem functions or technologies was the costs for each of them. Therefore, if costs were considered, the real choices could differ from the results of this survey. Further research should examine both the conditioned and actual preferences for natural or produced capital-based ES.

\section{Conclusion}

In this study, a questionnaire survey was conducted to investigate the preferences of Japanese people with diverse backgrounds toward natural and produced capital-based ES. The aim of this study was to understand and reflect the public preferences in the four scenarios of the PANCES project created by two axes. The scenarios were whether future society would move toward being "natural capital based" or "produced capital based," and whether the population concentrations would progress toward "urban compaction" or "dispersed population." Over a thousand respondents in Tokyo and Nanao city in Ishikawa prefecture answered the extent of their preferences for natural and produced capitalbased ES. The survey demonstrated the general tendency toward natural capital-based ES and that the trends differed depending on the attributes of the respondents. The males and respondents living in Tokyo favored produced capitalbased ES more than the females and respondents living in Nanao city. Older age and longer residence years affected the preference in which some of the natural capital-based ES were dominantly chosen. The results of stronger preferences toward natural capital-based ES than produced capitalbased ES worked positively in parallel with the significance of enjoying ES from natural capitals for the betterment of human well-being. This implication could substantiate the argument that produced capitals such as technologies could not replace natural capitals completely, but could only complement. These results were informative to understand the perception and preference of general public for an axe of PANCES scenarios, i.e., natural capital-basis vs. produced capital-basis. Further research investigating nationwide preferences is expected to overcome the limitations of this study such as the limited samples, simplification of the actual availability conditions for each option, and omission of the costs of various ES options.

Acknowledgements This research was funded by the Environment Research and Technology Development Fund (1-1303 and S-15, Ministry of the Environment, Japan) and the Future Earth initiative promotion activities (Future scenarios and governance of social-ecological systems in the Asia-Pacific region through enhancing synergy combining indigenous and local knowledge with scientific knowledge (ES-Scenario), Japan Science and Technology Agency).

\section{References}

Amano I, Kurisu K, Nakatani J, Hanaki K (2013) Effect of provided information and recipient's personality on risk perception of drinking water. J Jpn Soc Water Environ 36(1):11-22

Ataka S, Sekiguchi H, Sato S, Watanabe M (2008) An attempt of internet-survey on public attitudes towards science and technology. Discussion Paper No.45, 2nd Policy-Oriented Research Group, National Institute of Science and Technology Policy (NISTEP), Ministry of Education, Culture, Sports, Science and Technology (MEXT), JAPAN. http://data.nistep.go.jp/dspace/bitstream/11035 /466/1/NISTEP-DP045-FullJ.pdf. Accessed 20 June 2018

Bureau of General Affairs of Tokyo Metropolitan Government (2018) A map of municipalities of Tokyo. http://www.metro.tokyo.jp/ tosei/tokyoto/profile/gaiyo/kushichoson.html. Accessed 20 June 2018

Bureau of Urban Development of Tokyo Metropolitan Government (2011) Land use of Tokyo. http://www.toshiseibi.metro.tokyo.jp/ seisaku/tochi_c/pdf/tochi_3/tochi_all.pdf?1407. Accessed 20 June 2018

Cetinkaya G (2009) Challenges for the maintenance of traditional knowledge in the Satoyama and Satoumi ecosystems, Noto Peninsula, Japan. Hum Ecol Rev 16(1):27-40

Christensen RHB (2018) Ordinal-regression models for ordinal data, R package version 2018, 4-19. http://www.cran.r-project.org/packa ge $=$ ordinal $/$. Accessed 24 Apr 2018

Costanza R, de Groot R, Sutton P, van der Ploeg S, Anderson SJ, Kubiszewski I, Farber S, Turner RK (2014) Changes in the global value of ecosystem services. Glob Environ Change 26:152-158

Daly H (1995) On Wilfred Beckerman's critique of sustainable development. Environ Values 4:49-55

Díaz S, Demissew S, Carabias J, Joly C, Lonsdale M, Ash N, Larigauderie A, Adhikari JR, Arico S, Báldi A, Bartuska A, Baste IA, Bilgin A, Brondizio E, Chan KMA, Figueroa VE, Duraiappah A, Fischer M, Hill R, Koetz T, Leadley P, Lyver P, Mace GM, Martin-Lopez B, Okumura M, Pacheco D, Pascual U, Pérez ES, Reyers B, Roth E, Saito O, Scholes RJ, Sharma N, Tallis H, Thaman R, Watson R, Yahara T, Hamid ZA, Akosim C, Al-Hafedh Y, Allahverdiyev R, Amankwah E, Asah TS, Asfaw Z, Bartus G, Brooks AL, Caillaux J, Dalle G, Darnaedi D, Driver A, Erpul G, Escobar-Eyzaguirre P, Failler P, Fouda AMM, Fu B, Gundimeda H, Hashimoto S, Homer F, Lavorel S, Lichtenstein G, Mala WA, Mandivenyi W, Matczak P, Mbizvo C, Mehrdadi M, Metzger JP, Mikissa JB, Moller H, Mooney HA, Mumby P, Nagendra H, Nesshover C, Oteng-Yeboah AA, Pataki G, Roué M, Rubis J, Schultz M, Smith P, Sumaila R, Takeuchi K, Thomas S, Verma M, YeoChang Y, Zlatanova D (2015) The IPBES conceptual framework: connecting nature and people. Curr Opin Environ Sustain 14:1-16

FAO: Food and Agriculture Organization of the United Nations, Official homepage (2018). http://www.fao.org/giahs/giahsaroundthew orld/designated-sites/asia-and-the-pacific/notos-satoyama-andsatoumi/en/. Accessed 20 June 2018 
Fitter AH (2013) Are ecosystem services replaceable by technology? Environ Resour Econ 55(4):513-524. https://doi.org/10.1007/ s10640-013-9676-5

Goklany IM (2009) Technological substitution and augmentation of ecosystem services. In: Levin SA, Carpenter SR, Godfray HCJ, Kinzig AP, Loreau M, Losos JB, Walker B, Wilcove DS (eds) The princeton guide to ecology. Princeton University Press, Princeton, pp 659-669. https://doi.org/10.1515/9781400833023.659

Haaland C, van den Bosch CK (2015) Challenges and strategies for urban green-space planning in cities undergoing densification: a review. Urban For Urban Green 14(4):760-771. https://doi. org/10.1016/j.ufug.2015.07.009

Honey-Rosés J, Schneider DW, Brozović N (2014) Changing ecosystem service values following technological change. Environ Manage 53(6):1146-1157. https://doi.org/10.1007/s00267-014-0270-6

Huckauf A (2008) Biodiversity conservation and the extinction of experience. In: Dengler J, Dolnik C, Trepel M (eds) Flora, vegetation and nature conservation from Schleswig-Holstein to South America-festschrift for Klaus Dierßen on occasion of his 60th birthday. Mitt. Arbeitsgem. Geobot. Schleswig-Holstein Hamb, vol 65, pp 329-344

ICEM: International Centre for Environmental Management (2010) MRC strategic environmental assessment of hydropower on the Mekong mainstream, Summary of the final report. http://www. mrcmekong.org/assets/Publications/Consultations/SEA-Hydro power/SEA-FR-summary-13oct.pdf. Accessed 26 Sept 2018

IPBES: The Intergovernmental Science-Policy Platform on Biodiversity and Ecosystem Services (2016) The methodological assessment report on scenarios and models of biodiversity and ecosystem services. https://www.ipbes.net/sites/default/files/downloads/ pdf/2016.methodological_assessment_report_scenarios_model s.pdf. Accessed 20 June 2018

Jamieson D (1998) Sustainability and beyond. Ecol Econ 24(2-3):183-192

Japan Biodiversity Outlook Science Committee (2015) Report of comprehensive assessment of biodiversity and ecosystem services in Japan (Japan Biodiversity Outlook 2). Global Biodiversity Strategy Office, Biodiversity Policy Division, Nature Conservation Bureau, Ministry of the Environment, Japan, Tokyo

JSSA: Japan Satoyama Satoumi assessment (2010) Satoyama-Satoumi ecosystems and human well-being, socio-ecological production landscapes of Japan, Summary for Decision Makers. http://catal og.ipbes.net/system/assessment/62/references/files/255/origi nal/62_Japan_Satoyama_Satoumi_Assessment_\%282010\%29_ Satoyama-Satoumi_Ecosystems_and_Human_Well-being_Socio -ecological_Production_Landscapes_of_Japan_Summary_for_ Decision_Makers.pdf. Accessed 20 June 2018

Kearney AT (2017) Global cities 2017: leaders in a world of disruptive innovation. https://www.atkearney.com/documents/10192/12610 750/Global+Cities+2017+-+Leaders+in+a+World+of+Disru ptive+Innovation.pdf. Accessed 20 June 2018

Kowalski K, Stagl S, Madlener R, Omann I (2009) Sustainable energy futures: methodological challenges in combining scenarios and participatory multi-criteria analysis. Eur J Oper Res 197:1063-1074

MA: Millennium Ecosystem Assessment (2005) Ecosystem and human well-being: synthesis. Island Press, Washington DC

Miki A, Nakatani J, Hirao M (2010) Scenario analysis of drinking water usage applying life-cycle assessment for consumers. Environ Sci 23(6):447-458

Ministry of Internal Affairs and Communications (2014) Report of Study Group on Future Communities in Urban Areas. http:// www.soumu.go.jp/main_content/000283717.pdf. Accessed 20 June 2018

Ministry of Internal Affairs and Communications, 100 Cases of Regional Revitalization by ICT. http://www.soumu.go.jp/ main_sosiki/joho_tsusin/top/local_support/ict/jirei/index.html. Accessed 10 Aug 2018

Ministry of Land, Infrastructure, Transport and Tourism (2012) White Paper on Land, Infrastructure, Transport and Tourism in Japan, 2013. http://www.mlit.go.jp/hakusyo/mlit/h24/hakusho/h25/. Accessed 20 June 2018

Ministry of Land, Infrastructure, Transport and Tourism (2018) Comparison of function accumulation situation in each metropolitan area central area of metropolis, a material of Advisory Committee for Land to Earn. http://www.mlit.go.jp/common/001231519.pdf. Accessed 20 June 2018

Nanao city (2016) Present State of Environment of Nanao city. http:// www.city.nanao.lg.jp/kankyo/kurashi/recycling/kankyo/docum ents/00h28kankyonogenkyo_s.pdf. Accessed 20 June 2018

Nerima city office (2018) Productive green zone. https://www.city. nerima.tokyo.jp/kusei/machi/chiikichiku/seisanryokutitiku.html. Accessed 24 Aug 2018

Neumayer E (2003) Weak versus strong sustainability: exploring the limits of two opposing paradigms. Edward Elgar Publishing, Cheltenham

Oteros-Rozas E, Martín-López B, Daw TM, Bohensky EL, Butler JRA, Hill R, Martin-Ortega J, Quinlan A, Ravera F, Ruiz-Mallén I, Thyresson M, Mistry J, Palomo I, Peterson GD, Plieninger T, Waylen KA, Beach DM, Bohnet IC, Hamann M, Hanspach J, Hubacek K, Lavorel S, Vilardy SP (2015) Participatory scenario planning in place-based social-ecological research: insights and experiences from 23 case studies. Ecol Soc 20(4):32

PANCES (2017) Official homepage. http://pances.net/eng/index.html. Accessed 20 June 2018

Saito O, Kamiyama C (2015) Future scenarios and governance-evaluation of ecosystem and future scenario analysis in the Asia-Pacific region. In: Symposium of Society of Environmental Science, Japan, pp 12

Saito O, Kamiyama C, Hashimoto S, Matsui T, Shoyama K, Kabaya K, Uetake T, Taki H, Ishikawa Y, Matsushita K, Yamane F, Hori J, Ariga T, Takeuchi K (2018) Co-design of national-scale future scenarios in japan to predict and assess natural capital and ecosystem services. Sustain Sci. https://doi.org/10.1007/s1162 $5-018-0587-9$

Schaubroeck T (2018) Towards a general sustainability assessment of human/industrial and nature-based solutions. Sustain Sci 13:1185-1191. https://doi.org/10.1007/s11625-018-0559-0

Secretariat of the Convention on Biological Diversity (2002) Brochure on 'Traditional Knowledge and the Convention on Biological Diversity'. https://www.cbd.int/doc/publications/8j-brochure-en. pdf. Accessed 8 Aug 2018

Simaika JP, Samways MJ (2010) Biophilia as a universal ethic for conserving biodiversity. Conserv Biol 24(3):903-906. https://doi.org /10.1111/j.1523-1739.2010.01485.x

Specht K, Siebert R, Hartmann I, Freisinger UB, Sawicka M, Werner A, Thomaier S, Henckel D, Walk H, Dierich A (2014) Urban agriculture of the future: an overview of sustainability aspects of food production in and on buildings. Agric Hum Values 31:33-51. https://doi.org/10.1007/s10460-013-9448-4

Tanaka T, Iwamoto S, Nishina D (2014) A study on the preferable urban structure of provincial small town in the depopulation tendency. J Environ Eng AIJ 79(697):286-296

Uk NEA (2011) The UK National Ecosystem Assessment: synthesis of the key findings. UNEPWCMC, Cambridge

Van Vuuren DP, Kok MTJ, Girod B, Lucas PL, De Vries B (2012) Scenarios in global environmental assessments: key characteristics and lessons for future use. Glob Environ Change 22(4):884-895

Wells NM, Lekies KS (2006) Nature and the life course: pathways from childhood nature experiences to adult environmentalism. Child Youth Environ 16(1):1-24

Wilson EO (1984) Biophilia. Harvard University Press, Cambridge 